\title{
An Empirical Study on Determinants of Flow of Social Network Games on Facebook
}

\begin{tabular}{|c|c|}
\hline \multicolumn{2}{|c|}{ Hanh-Nguyen Tang* $\cdot$ Jaehun Joo** } \\
\hline 1. Introduction & 5.2 Confirmatory Factor Analysis and \\
\hline 2. Literature Review & Validity \\
\hline 2.1 Flow Theory & 5.3 Hypothesis Test \\
\hline 2.2 Social Network Games & 6. Discussion and Implications \\
\hline 3. Research Model and Hypotheses & 6.1 Discussion \\
\hline 4. Research Design & 6.2 Theoretical Implications \\
\hline 4.1 Questionnaire Design & 6.3 Practical Implications \\
\hline 4.2 Data Collection & 7. Conclusion \\
\hline 5. Research Analysis & References \\
\hline $\begin{array}{l}\text { 5.1 Demographics and Exploratory Factor } \\
\text { Analysis }\end{array}$ & $<$ Abstract $>$ \\
\hline
\end{tabular}

\section{Introduction}

Social network site (SNS) offers a variety of interesting applications. SNS is like a miniature of the world we are experiencing today. It is virtual environment but it tries to provide the users with real-feeling applications as much as possible, especially the real social aspect.
Almost the interactivity between human beings can be found through different applications in the SNS. People express and share their thoughts or feelings to the network relationship, chat or gossip to each other, gift their buddy on the special occasions, even invite and organize the events, etc. These things are so familiar features to SNS users. Among the entertaining

\footnotetext{
* Ph. D. Student, Department of Information Management, Dongguk University-Gyeongju, robomitsumi@yahoo.com

** Professor, School of Management, Dongguk University-Gyeongju, Corresponding author, givej@dongguk.ac.kr
} 
applications, social network game (SNG) is prominently outstanding in drawing user attention and user participation. It exploits the social aspect of SNS and coordinates the recreational nature of gaming at the same time. That's why SNS users find social games so new, fascinating and contemporary. It attracts various types of SNS users. Social games have really become a social phenomenon. A new study about social games in the U.S (Magic Media Futures, 2012) found that 38 percent of social network users currently play social games, compared to 36 percent last year. The social network gamer spent an average of $\$ 78$ on SNGs in 2011 .

It has been over several years since SNG has been released on social network sites. It is always a leading wave of SNS users when they want to recreate and amuse themselves. The SNG providers try to keep transforming their social games. The new games and the new versions of the existing social games are always released every few months. Currently, the game named Candy Crush Saga is to create a real craze for the global net citizen on Facebook. In December, 2012 the game reached over ten million downloads (Woollaston, 2013). It is the most popular application on Facebook and the highest-grossing application in the Apple and Google application stores (Candy Crush Saga Wikipedia). Is there any reason what makes people enjoy SNG? Some researchers have made their efforts to study about SNG (Shin and
Shin, 2011; Wu, Wang, Chang and $\mathrm{Xu}, 2010$; Wohn et al., 2011; Wei, Yang and Adamic, 2010; Ines and Abdelkader, 2011; Chang and Chin, 2011; Sung et al., 2010; Kirman, 2010). For entertainment-based application, flow theory is typical the most used and popular theory to explain player's behavior (Sweetser and Wyeth, 2005; Murphy, 2011; Csikszentmihalyi, 1990; Schell, 2008). Some previous studies employed flow theory to explain user behaviors on entertainment-based application, SNG, or online game (Hsu and Lu, 2004; Shin and Shin, 2011; Wu et al., 2010; Wu, $\mathrm{Li}$ and Rao, 2008; Choi and Kim, 2004). However, those researches have some limitations. One of its shortcomings is not to point out the specific antecedents of flow. From that point, this paper aims to complete the existing researches on flow of SNG by identifying determinants affecting flow of SNG. Among several available SNSs such as Facebook, LinkedIn, Google+, etc. the paper addresses to Facebook because its users are most diverse in age, nationality, career, etc.

From addressing the defect of existing studies on SNG and Facebook attractiveness, this paper aims to analyze the flow experience of user when playing SNG and antecedents of the flow. This study identifies the determinants of SNG flow, in the particular context which is Facebook. The research will focus on the social game's characteristics itself to interpret the players' flow experiences instead of the external 
factors like gender, age, social influence or the subjective factors of the player like subjective norm, self-efficacy, experience, and personality traits. Analysis of the determinants is quite necessary for the SNG providers, because it can be helpful to explain the flow experiences of players. The social game developers may gain more information about their games from customers, and come up with more ideas to improve the games and enhance the player experiences. The SNG providers can utilize these factors for the development and expansion of their SNG.

\section{Literature Review}

\subsection{Flow Theory}

The original concept of flow is introduced by Csikszentmihalyi $(1975,1988,1990)$. It is defined as the holistic feeling that people experience when they are totally involved in doing something. From the concept of psychology area, it has been widely adopted in various research fields nowadays. Specially, when people are in the situation that they act with a highly intense concentration on a specific focus and they tend to ignore other external thing. At that time, they narrow their awareness to the activity itself and become absorbed in those activities. They also feel the strong control over the environment and lose their self-consciousness. That kind of state is defined as flow state or these indications are characterized to flow state ( $\mathrm{Wu}$ et al., 2010). And moreover, through continuous interaction with the activities, they feel in control of the situation and develop an awareness of time and space separation (Csikszentmihalyi, 1990). Finally, when people are entirely embedded in the activity, they will tend to put more effort on doing that activity which even does not make the financial benefit. But it could help them enjoy more highly, and this is the so called flow experience. The typical examples of flow experience in human daily activities are such like chess playing, rock climbing, dancing, music composing, and even web surfing (Phang and Kankanhalli, 2009).

Besides the boundary of psychology field, flow theory has been applied to information systems field to explain the various kind of phenomenon, for example online interactive relationship between people and computer information systems (Hoffman and Novak, 1996; Chen, Wigand, and Nilan, 1999), online customer behavior (Koufaris, 2002; Koufaris, Kambil, and LaBrabera, 2002; Korzaan, 2003; Novak et al., 2000; Sharafi, Hedman, and Montgomery, 2006; Skadberg and Kimmel, 2004), user-customized products online (Kamis, Koufaris and Stern, 2008), computer-mediated communication (Trevino and Webster, 1992), online game (Choi and Kim, 2004; Hsu and Lu,. 2004), and human-computer interaction (Finneran and Zhang, 2003; Finneran and 
Zhang, 2005).

Although flow has been adapted to a lot of topics in MIS such as human-computer interactions, web sites, consumers' online shopping behavior, user-customized products online, etc.; flow is still the main theory used when studying about an entertainment-oriented technology, and entertainment-based application. Flow has been widely considered and accepted to be one of the fundamental causes that people play games (Murphy, 2011; Csikszentmihalyi, 1990; Schell, 2008). Flow is the nature of games as the primary goal of games is to create the recreation for user through the intrinsic motivation, which is highly related to flow concept. Hence, the most critical issues for game designers and game providers are not whether flow is important, but, rather, how to maintain the players in flow with their games, and how long their games can keep the players in flow. This study concentrates on SNG which is also a certain form of game. Therefore, employing flow theory as the background theory for the paper is understandable. Moreover, researching on determinants of flow of SNG could lead to a certain promising result for game providers to enhance the flow in their games. Some previous studies are related to flow and games, e.g. Hsu and $\mathrm{Lu}$ (2004) utilized technology acceptance model (TAM) with social influence and flow experience to suggest their opinion why people play online games; Shin and Shin (2011) used theory of reasoned action (TRA) and flow to make a research model on why people play SNGs; Wu et al. (2010) combined the design factors and flow theory perspective to explain for people stickiness to playing SNS-based entertainment applications; $\mathrm{Wu}, \mathrm{Li}$ and Rao (2008) were interested in why people enjoy virtual game worlds. Furthermore, flow experience or optimal experience is believed to influence user's behavioral intention in online game communities according to the previous studies (Choi and Kim, 2004; Hsu and Lu, 2004; Wu et al., 2010).

\subsection{Social Network Games}

Simply understanding, a social network game is a type of online game that is played through SNS, it opens a new type of social phenomenon (Social Network Game Wikipedia; Williams, 2006). More formal and functional, social network games is casual game with social network integration (Causal game Wikipedia). Since the advent of computer games, there have been lots of game types, typically video game console (some famous examples are PlayStation, Xbox 360, and Wii), and offline game (which the user just downloads the game to their device such as personal computer, laptop, mobile phone, etc and sets up to play). Online game is very diverse, and SNG is one type among the plentiful kinds of online game. There are several famous social game companies like Zynga, Playfish, 5 Minutes, Playdom, Kabam, etc. Social games distinguish 
it with other kinds of game due to its special features. Table 1 show the unique traits of SNG which distinguish itself with video game console, offline game, and other types of online games.

Social game providers offer SNG for free for every user on SNS. Where they can get the profit of benefit from the social games? The social game companies also have their own ways to earn money from the social games. Because they provide the social games for free, they employ the different and new methods to get money. Table 2 shows the monetizing ways of social game companies. The paper is intended to suggest some practical implications for the SNS providers, so presenting the monetizing ways of social games is not useless for the practitioners. Because the goal of understanding the determinants of flow, then trying to enhance flow, and finally is to serve for the purpose of

$<$ Table $1>$ Distinct features of the social games

\begin{tabular}{|c|c|c|}
\hline Feature & Explanation & References \\
\hline $\begin{array}{l}\text { Multiplayer and } \\
\text { asynchronous gameplay }\end{array}$ & $\begin{array}{l}\text { - The game doesn't limit the number of player. Different users } \\
\text { can play the same game, but not need to play at the same time. } \\
\text { - This feature makes the social games itself become more } \\
\text { convenient and easily for the users to play. }\end{array}$ & Radoff, 2011 \\
\hline Community & $\begin{array}{l}\text { - The social game leverages the player's social network through } \\
\text { the hosted SNS to build the gaming community for the player. } \\
\text { It is called "neighbors" or "allies". } \\
\text { - When the players connect to each other through a certain social } \\
\text { game, it is their own social game community. } \\
\text { - The more members in the community, the faster the player can } \\
\text { complete the quests/challenges of the game. }\end{array}$ & $\begin{array}{l}\text { Radoff, } 2011 \\
\text { Wohn et al., } \\
\quad 2011\end{array}$ \\
\hline No victory conditions & $\begin{array}{l}\text { - The social game never ends and no "winner". Instead, it has } \\
\text { "quests" or "missions" for players to complete. }\end{array}$ & Radoff, 2011 \\
\hline Continuous goals & $\begin{array}{l}\text { - When the user attains the higher level or finishes the goals, } \\
\text { the goals become more challenging and time consuming for the } \\
\text { users to achieve. }\end{array}$ & Bjork, 2010 \\
\hline Gaming capitals & $\begin{array}{l}\text { - These things indicate user progress and accomplishments, for } \\
\text { example badges, trophies, and accolades. It represents user's } \\
\text { effort and performance in playing the game. } \\
\text { - The achievements are visible to their network of gaming friends. }\end{array}$ & $\begin{array}{l}\text { Social Network } \\
\text { Game } \\
\text { Wikipedia }\end{array}$ \\
\hline Real time events & $\begin{array}{l}\text { - The timing of phenomena, or to complete certain actions in } \\
\text { the game refers to the real world (real time). } \\
\text { - For example: } 1 \text { corn crop requires } 8 \text { hours to grow up, the user } \\
\text { must wait } 8 \text { hours in real time to harvest that crop. }\end{array}$ & Bjork, 2010 \\
\hline Virtual currency & $\begin{array}{l}\text { - The user can purchase virtual money with real-world money. } \\
\text { - It uses to buy the premium and special items/products, or } \\
\text { upgrades in game. }\end{array}$ & Radoff, 2011 \\
\hline
\end{tabular}


$<$ Table 2> Ways to make money through social games

\begin{tabular}{|c|c|c|}
\hline Method & Detail & References \\
\hline Selling virtual goods & $\begin{array}{l}\text { - By selling virtual money. The user can purchase virtual goods like } \\
\text { power-ups, avatar accessories, decorative items, or premium items } \\
\text { by using virtual money. } \\
\text { - It is represented over } 90 \% \text { of all revenue generated by the world's } \\
\text { top social game developers. }\end{array}$ & $\begin{array}{l}\text { Gorby, } 2011 \\
\text { Taylor, } 2010 \\
\text { Smith, } 2010\end{array}$ \\
\hline Advertising & $\begin{array}{l}\text { - Banner: CPMs around } \$ 2 \text {. } \\
\text { - Video: tend to be higher-priced, either by CPMs ( } \$ 35+\text { CPM in } \\
\text { social games) or cost-per-completed-view. } \\
\text { - Product placement: injecting a brand name or product in game, } \\
\text { for example branded in-game goods or in-game quests. Some brand } \\
\text { names already appeared in social games like MacDonald, } \\
\text { Wal-Mart, BestBuy. }\end{array}$ & $\begin{array}{l}\text { Gorby, } 2011 \\
\text { Smith, } 2010\end{array}$ \\
\hline
\end{tabular}

entertaining the players and making benefit for the providers. For more information, Figure 1 shows the top list of 25 popular Facebook games by Daily Active Users on May 2013 (Maiberg, 2013).

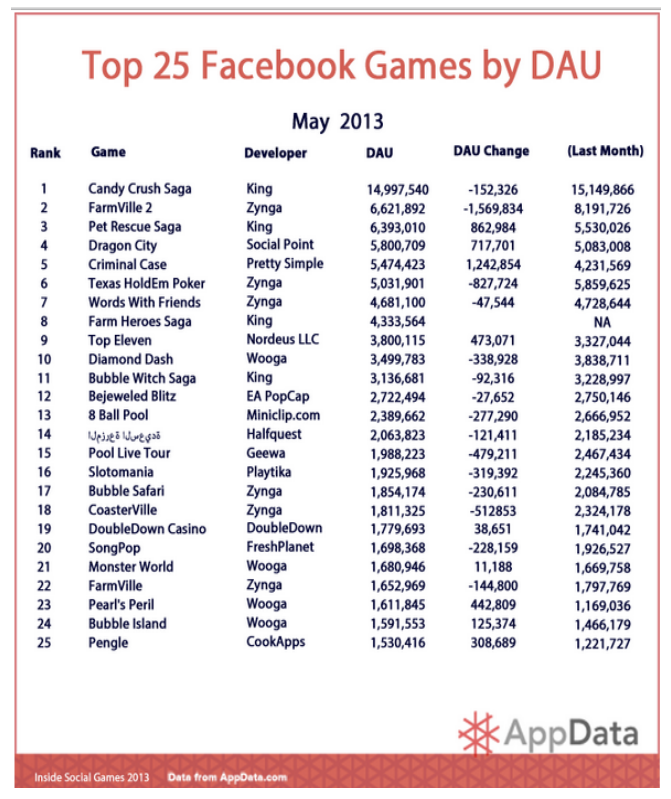

$<$ Figure 1> Top 25 Facebook games of May 2013 by Daily Active Users

\section{Research Model and Hypotheses}

Flow. As literature study on area of entertainment applications has shown that joyful emotion and enjoyed experience play an important role in users' playing (Shin and Shin, 2011). In various ways, flow could be represented as perceived enjoyment or perceived playfulness in entertaining area, for instance playful actions in Facebook (Rao, 2008). There are many previous studies which employed flow as an intrinsic feeling or motivation for entertainment applications. According to Davis et al. (1992), from a motivational perspective there are two kinds of motivations which are intrinsic and extrinsic affect to the amount of efforts people put in the use of computers. In communities of entertainment technology, the significance of extrinsic motivation which is usually shown as perceived usefulness will 
decrease (Hsu and Lu, 2004). As online games for leisure and pleasure, intrinsic factors, other than extrinsic factors, are the salient motivating factors in behavior intention (Koo, 2009).

Besides, it is believed that flow experience exhibits an important role in continuance use of SNS based entertainment applications (SNSEAs) (Wu et al., 2010). Additionally, researches also have shown that participants in flow could sense highly control of behavior, playfulness and enjoyment. Consequently, flow experience would often make people pleasure and more relaxation (Csikszentmihalyi, 1975; Csikszentmihalyi, 1990). Moreover, as also presented in the above literature review of flow theory, flow theory provides an appropriate lens to look at entertainment-oriented technology and entertainment-based application. Besides, social games which include the different and unique characteristics (like socially cooperation playing and asynchronous playing mode) distinguishing it to the rest games promisingly bring the totally new feeling and experience to players. Therefore, based on all of the above arguments, flow theory has been chosen as a theoretical background to discover users' experience of playing social games in this paper. In this paper, flow is defined as the enjoyment which the user gets by playing social games, together with a control over the game and the focus entirely on the playing interaction. These feelings make the user happier, more excited about playing social games and so the user could enjoy the social games more and more.

Using flow theory based on the learning of previous studies on the same or similar issues, and the knowledge of SNG, we develop a new research model to reflect the formation progress

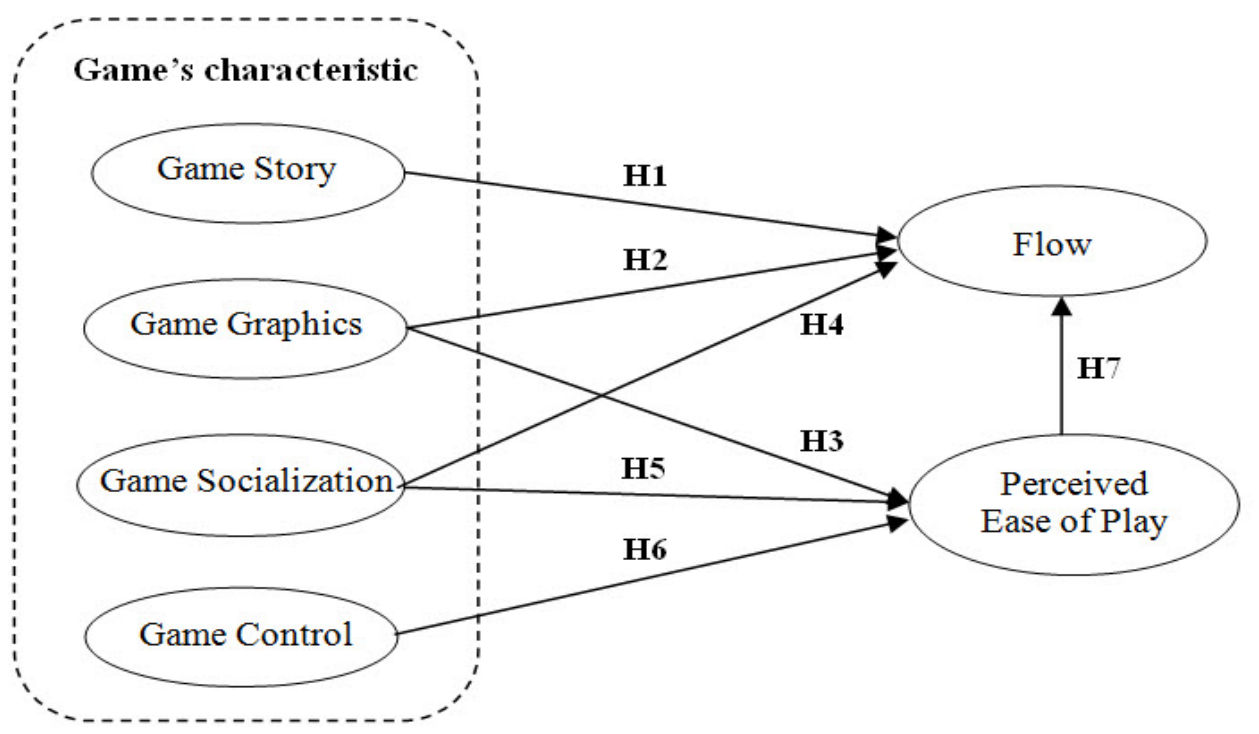

<Figure 2> Research model 
of flow experience when users play SNG as shown in Figure 2. The research model includes four prominent characteristics of social games (game story, game graphics, game socialization, and game control) which are considered as antecedents of flow, and perceived ease of play as an intermediate variable contributing to the formation of flow. The four determinants have been inspired by the literature review, prior studies on SNG, virtual games, and online games.

Game story. Every SNG has its own story and genre. The different genres of SNG can be classified as several types, including board, word, simulation, arcade, role-playing, and action games (Wohn, 2011). Depending on the genre, the developers will build the game story which is suitable to create the most attractive game to the players. A nice game story could bring a lot of advantages to the game. An interesting story could motivate players to explore the game, to continuously return to the virtual world, and to see the in-game characters through to the end. Moreover, an attractive story can make a game more enjoyable by evoking fantasies and sense of curiosity in players; or by the other expressing way, it means game story can enhance the game enjoyment and playfulness of users (Pearce 2003; Wu et al., 2008).

These days, the social game developer tries to inject the facts in real life to the game. The aim is to make the game become more real and closer to the players. For instance, it is easy to change the game's theme, buy the specialized items/products during the special occasions such like Christmas, New Year or Easter. Besides, the challenges/requests related to these events also appear for the user to achieve. Hence, this construct refers to the main content of the game, and how the plot of the game is developed and happened to attract the users to feel interesting, fascinating about the game.

\section{H1 - Game story has a positive effect on user's flow of $S N G$.}

The relationship between game story and perceived ease of play isn't hypothesized in the research model because of several reasons. It is quite difficult find any previous evidences to support the relationship between game story and perceived ease of play. Game story is diverse, and nothing can be said about how easy or difficult the game will be if we just base on the content of the game. For example, the story of Angry Birds game is that the greedy pigs stole the birds' eggs, and therefore the birds decided to revenge and take the eggs back by using the unique powers of each bird to destroy the pigs' defenses. Another popular game is car racing game. The racer must control the car to overcome the obstacles on the racetrack and pass the destination first. It seems like the car racing game is easier to play than the Angry Birds game. But Angry Birds turns to be very easy for playing in reality, compared to car racing. In 
addition, there is no clear previous research which hypothesized the relationship between game story and perceived ease of play. Therefore, the paper doesn't suppose this relationship.

Game graphics. Each SNG is designed differently to be fit with its content. The visual side of the game is also quite important. Some users feel sympathetic with this kind of interface design, while the others do not. Sometimes the users are attracted by the visual design of the game then they started to learn about the game more deeply. It leads to the user stickiness to the game. Moreover, the game designers could take an account into how well the graphics of the game are developed to represent the reality to increase the quality of the gaming experience. Therefore, the players could perceive the games as amazingly real and alive, so they enjoy playing them more (Wu et al., 2008).

This construct refers to the graphics design of the game or the visual information that players receive during the game, which are presented in the form of pictures, images, or drawings in the game (Wu et al., 2008); and how it attracts the users and makes them feel comfortable with the visual interface of the game.

H2 - Game graphics has a positive effect on user's flow of SNG.

H3 - Game graphics has a positive effect on user's perceived ease of play of SNG

Game socialization. As its name, the socialization is one of the important feature and unique characteristic of SNG. It provides the social interaction inside the game between the players through various ways such as giving gifts, visiting neighbor, posting news feed, helping each other do some tasks on the game, etc. Through these actions, the users can partly improve their social relationship positively. This construct is defined as the extent to which the game provides the different ways to create and improve the interactivity between the players to help them maintain and enhance the social relationships.

\section{H4 - Game socialization has a positive effect on user's flow of SNG. \\ H5 - Game socialization has a positive effect on user's perceived ease of play of SNG.}

Game control. Playing games is not a simple action because it usually requires the hand-eye-coordination and often causes physical or physiological reactions (Eskelinen, 2001). To play the games proficiently, in some extent the players need to practice the physical coordination of their hands and eyes to get a smoother movement. Then they can control the games better. It could be view as an exercise of control systems (Juul, 2001). Game control refers to the mechanism that allows players to manage and direct a game by using keyboard and mouse. The game control is important because it impacts players' feelings on how the 
game is easy to manage (Wu et al., 2008). This construct refers to the physical interaction between the player and the game, how the player controls the objects in the game, or how to play the game in practice (like the users need to perform which actions such as clicking mouse, dragging mouse, grabbing mouse, etc). The extent to how intuitively understandable, easy to learn, and easy to use the control of the game is designed could affect the users in term of the ease of play of the game.

\section{H6 - Game control has a positive effect on user's perceived ease of play of $S N G$.}

There is an argument about the influence of game control on flow. Wu, Li and Rao (2008) gave the direct relationship between game control and game enjoyment in their paper. However, this paper doesn't suppose the relationship between game control and flow. The reason is because of the intermediate role of perceived ease of play. This paper assumes that game control does affect on flow, but through perceived ease of play instead of directly impacting on flow. The research model of $\mathrm{Wu}$, $\mathrm{Li}$ and Rao (2008) doesn't have the appearance of perceived ease of play; and they didn't consider the role of this construct. Also in the above given paper, the authors supposed the relationship between game control and enjoyment, but their explanation showed the intermediate role of perceived ease of play between game control and enjoyment. They explained that "When players have difficulties in controlling in-game character body movement or in weapon aiming, they perceive the online game as having low play value and thus are less likely to continue, let alone to have fun. On the contrary, when the control is easy to use, players will consider the online game as a decent and attractive one." Therefore, it is probably more logical to hypothesize the relationship such like this "game control"-"perceived ease of play"-“flow".

Perceived ease of play. The construct of perceived ease of play is adopted from TAM. Based on the original model, the technology acceptance is happened through the user's perceived usefulness and perceived ease of use. In case of entertainment, the role of perceived usefulness is not much salient (Hsu and $\mathrm{Lu}$, 2004; Koo, 2009). Gaming is for relaxing purpose so considering the role of ease of use is pretty rational. Ease of use refers to the extent to which the social games is easy to learn and play by the users themselves after the basic directions of the game, so they can handle the game later without any troubles when the game has been growing and not simple like the first period. There are literature indicating that there is a positive relationship between perceived enjoyment and perceived ease of use for the multimedia system (Venkatesh, 2000; Hsu and Lu, 2007).

H7 - Perceived ease of play has a positive effect on user's flow of SNG. 
$<$ Table 3> Summary of constructs

\begin{tabular}{|c|c|c|}
\hline Construct & Definition & References \\
\hline Game Story & $\begin{array}{l}\text { - The story of the game } \\
\text { - The way which the plot of the game is happened to attract the } \\
\text { users to feel interesting, fascinating about the game. }\end{array}$ & $\begin{array}{l}\text { Wohn et al., } 2011 \\
\text { Pearce, } 2003 \\
\text { Wu et al., } 2008\end{array}$ \\
\hline Game Graphics & $\begin{array}{l}\text { - The visual side of the game is also quite important. Some users } \\
\text { feel sympathetic with this kind of interface design, while the } \\
\text { others don't. } \\
\text { - The interface design of the game } \\
\text { - The way which the graphics attracts the users and makes them } \\
\text { feel comfortable. }\end{array}$ & Wu et al., 2008 \\
\hline $\begin{array}{c}\text { Game } \\
\text { Socialization }\end{array}$ & $\begin{array}{l}\text { - One of the important feature and unique characteristic of SNG. } \\
\text { Example: giving gifts, visiting neighbor, posting news feed, etc. } \\
\text { - The extent to which the game provides the different ways to } \\
\text { create and improve the interactivity between the players to help } \\
\text { them maintain and enhance the social relationships }\end{array}$ & $\begin{array}{l}\text { Wohn et al., } 2011 \\
\text { Wu et al., } 2010 \\
\text { Choi and Kim 2004; } \\
\text { Wu et al., } 2008 \\
\text { Sweetser and Wyeth, } 2005\end{array}$ \\
\hline Game Control & $\begin{array}{l}\text { - The physical interaction between the player and the game. } \\
\text { - The way how the player controls the objects in the game, or } \\
\text { how to play the game in practice (e.g. the users need to perform } \\
\text { which actions such as clicking mouse, dragging mouse, etc) } \\
\text { - The extent to how intuitively understandable, easy to learn, and } \\
\text { easy to use the control of the game is designed. }\end{array}$ & $\begin{array}{l}\text { Saarenpää et al., } 2009 \\
\text { Bruner et al., } 2005 \\
\text { Juul } 2001 \\
\text { Eskelinen } 2001 \\
\text { Wu et al., } 2008\end{array}$ \\
\hline $\begin{array}{c}\text { Perceived Ease } \\
\text { of Play }\end{array}$ & $\begin{array}{l}\text { - The extent to which the social games is easy to learn and play } \\
\text { by the users themselves after the basic directions of the game. } \\
\text { - The user can handle the game later without any troubles when } \\
\text { the game has been growing and not simple like the first period. }\end{array}$ & $\begin{array}{l}\text { Davis, } 1989 \\
\text { Hsu and Lu, } 2007 \\
\text { Venkatesh, } 2000\end{array}$ \\
\hline Flow & $\begin{array}{l}\text { - Enjoyment which the user gets by playing social games. } \\
\text { - A control over the game and focus entirely on the playing } \\
\text { interaction. } \\
\text { - It makes the user happier, more excited about playing social } \\
\text { games and so the user could enjoy the social games more and } \\
\text { more. }\end{array}$ & $\begin{array}{l}\text { Shin and Shin, } 2011 \\
\text { Wu et al., } 2010 \\
\text { Rao, } 2008\end{array}$ \\
\hline
\end{tabular}

Table 3 gives a general glance on all the constructs in the research model, together with their concise definitions, reference sources for supporting the hypotheses.

\section{Research Design}

\subsection{Questionnaire Design}

The scale which is used to measure the question item is Likert's five scale, from 1 
$<$ Table 4> Survey instrument for the research model

\begin{tabular}{|c|c|c|c|}
\hline Construct & Items & Description & Sources \\
\hline \multirow{4}{*}{ Game Story } & GS1 & The story of the game is attractive. & \multirow{4}{*}{$\begin{array}{l}\text { Jeanne et al., } 2009 \\
\text { Wu et al., } 2008\end{array}$} \\
\hline & GS2 & The story of the game is interesting. & \\
\hline & GS3 & The story of the game is appealing. & \\
\hline & GS4 & The story of the game is always evolving. & \\
\hline \multirow{5}{*}{ Game Graphics } & GG1 & The graphics of the game is nice. & \multirow{5}{*}{ Wu et al., 2008} \\
\hline & GG2 & The graphics of the game is appealing. & \\
\hline & GG3 & The graphics of the game is comfortable for eyes. & \\
\hline & GG4 & I am satisfied with the graphics of the game. & \\
\hline & GG5 & I like the graphics of the game. & \\
\hline \multirow{6}{*}{$\begin{array}{l}\text { Game } \\
\text { Socialization }\end{array}$} & GSO1 & $\begin{array}{l}\text { The game well supports the interaction between players } \\
\text { (message, news feed, email, etc) }\end{array}$ & \multirow{6}{*}{$\begin{array}{l}\text { Wu et al., } 2010 \\
\mathrm{Fu}, \mathrm{Su} \text { and } \mathrm{Yu}, 2009\end{array}$} \\
\hline & GSO2 & The game supports communities within the game. & \\
\hline & GSO3 & I feel connected with other players when playing the game. & \\
\hline & GSO4 & $\begin{array}{l}\text { I feel cooperative toward other players when playing the } \\
\text { game. }\end{array}$ & \\
\hline & GSO5 & $\begin{array}{l}\text { The cooperation in the game is helpful when playing the } \\
\text { game. }\end{array}$ & \\
\hline & GSO6 & $\begin{array}{l}\text { I strongly cooperate with other players when playing the } \\
\text { game. }\end{array}$ & \\
\hline \multirow{4}{*}{ Game Control } & GC1 & The controls of the game are easy to learn. & \multirow{4}{*}{$\begin{array}{l}\text { Wu et al., } 2010 \\
\text { Wu et al., } 2008\end{array}$} \\
\hline & GC2 & The controls of the game are easy to use. & \\
\hline & GC3 & The controls of the game are easy to handle. & \\
\hline & GC4 & I feel comfortable with the controls of the game. & \\
\hline \multirow{5}{*}{$\begin{array}{l}\text { Perceived Ease } \\
\text { of Play }\end{array}$} & PE1 & Playing the game is easy for me. & \multirow{5}{*}{$\begin{array}{l}\text { Jeanne et al., } 2009 \\
\text { Hsu and Lu, } 2007\end{array}$} \\
\hline & PE2 & $\begin{array}{l}\text { It's easy to play the game and handle the tasks when I'm } \\
\text { familiar with the game. }\end{array}$ & \\
\hline & PE3 & I feel a sense of control over the game. & \\
\hline & PE4 & I play without thinking about how to play. & \\
\hline & PE5 & Becoming skillful at playing game is easy for me. & \\
\hline \multirow{4}{*}{ Flow } & FL1 & I feel joyful when playing the game. & \multirow{4}{*}{$\begin{array}{l}\text { Lin, Wu and Tsai, } \\
2005 \\
\text { Moon and Kim, } 2001 \\
\text { Van der Heijden, } \\
2004\end{array}$} \\
\hline & FL2 & I feel relaxing when playing the game. & \\
\hline & FL3 & I feel falling into the game when playing the game. & \\
\hline & FL4 & $\begin{array}{l}\text { I feel forgetting worries about everyday life when playing } \\
\text { the game. }\end{array}$ & \\
\hline
\end{tabular}

means strongly disagree to 5 means strongly agree. Respondents are social network users who are playing SNG or have experienced on playing SNG on Facebook. Table 4 represents the measurement items for the constructs in the research model.

\subsection{Data Collection}

Prior to the main survey, the pilot test has 
been conducted to test the appropriation of the measurement items. The questionnaire is made using GoogleDocs service in both English and Vietnamese. Then, it is distributed through Facebook site and the different social games' communities also on Facebook. The data collection has 126 responses which is summed both responses from the English and Vietnamese questionnaire. Exploratory factor analysis and reliability test have been conducted for the pilot data. The results were similar with our estimation. The scales show good reliability with Cronbach's alphas $>0.7$. The exploratory factor analysis also shows a good result with 6 variables converging to 6 factors. From these results, we could continue collecting more data to perform the main analysis. From the good results of pilot test, the main sampling has been performed with the goal to collect data for testing the research model. GoogleDoc service has been utilized to distribute the questionnaire and support collecting the data. Finally, 280 valid responses were gathered.

\section{Research Analysis}

\subsection{Demographics and Exploratory Factor Analysis}

Table 5 shows the demographical information got from the sample. Most of the respondents are female $(61.43 \%)$ and they are from 20-29 years old (43.57\%). 58.21\% of the respondents has used Facebook for more than 2 years. The frequency of Facebook usage is fairly high, 3-5 days/week with $32.14 \%$ or everyday by $35.71 \%$. And every time they use Facebook, it usually takes them 1 hour-2 hours to do something on Facebook. The next is more detailed demographics about users' SNG habit. 37.14\% of respondent has played SNG on Facebook about 3 months- 6 months. The dominant frequency of playing SNG is everyday (29.64\%). 41.07\% spends about 30 minutes-1 hour playing SNG for each time. Most of the respondents just play 1 game (53.21\%), however there are still the other portions playing several games at the same time, e.g. $30.36 \%$ playing 2 games and $12.14 \%$ playing 3 games.

By using SPSS software, the results of exploratory factor analysis are shown in Table 6. The eigenvalue of six factors are extracted and all of the eigenvalue are over 1.0. Reliability is represented by Cronbach's alpha value and the acceptable value should be equal or greater 0.7 $(>=0.7)$. All of the constructs show the good reliability. The Cronbach's alphas of six factors are well satisfactory with all the values are over 0.7, which indicate the highly internal consistency of each construct. 
「정보시스템연구」제23권 제1호, 2014년 3월

$<$ Table $5>$ Characteristics of respondents (total $=280$ ).

\begin{tabular}{|c|c|c|c|}
\hline Measure & Items & Frequency & Percentage $(\%)$ \\
\hline \multirow{2}{*}{ Gender } & Male & 108 & 38.57 \\
\hline & Female & 172 & 61.43 \\
\hline \multirow{5}{*}{ Age } & $10-19$ & 53 & 18.93 \\
\hline & $20-29$ & 122 & 43.57 \\
\hline & $30-39$ & 55 & 19.64 \\
\hline & $40-49$ & 47 & 16.79 \\
\hline & $50-59$ & 3 & 1.07 \\
\hline \multirow{4}{*}{ How long has used Facebook } & Less than 6 months & 27 & 9.65 \\
\hline & 6 months-1year & 35 & 12.50 \\
\hline & 1 year-2 years & 55 & 19.64 \\
\hline & More than 2 years & 163 & 58.21 \\
\hline \multirow{5}{*}{ How often uses Facebook } & Everyday & 100 & 35.71 \\
\hline & 1-2 days/week & 76 & 27.15 \\
\hline & 3-5 days/week & 90 & 32.14 \\
\hline & Every few weeks & 14 & 5 \\
\hline & Less often & 0 & 0 \\
\hline \multirow{5}{*}{$\begin{array}{l}\text { How long each time uses } \\
\text { Facebook }\end{array}$} & Less than 30 minutes & 55 & 19.64 \\
\hline & 30 minutes- 1 hour & 77 & 27.50 \\
\hline & 1 hour -2 hours & 112 & 40 \\
\hline & 2 hours -3 hours & 28 & 10 \\
\hline & More than 3 hours & 8 & 2.86 \\
\hline \multirow{4}{*}{$\begin{array}{l}\text { How long has played social } \\
\text { game on Facebook }\end{array}$} & Less than 3 months & 87 & 31.07 \\
\hline & 3 months- 6 months & 104 & 37.14 \\
\hline & 6 months-1 year & 75 & 26.79 \\
\hline & More than 1 year & 14 & 5 \\
\hline \multirow{5}{*}{$\begin{array}{l}\text { How often plays social game } \\
\text { on Facebook }\end{array}$} & Everyday & 83 & 29.64 \\
\hline & 1-2 days/week & 71 & 25.36 \\
\hline & 3-5 days/week & 63 & 22.50 \\
\hline & Every few weeks & 39 & 13.93 \\
\hline & Less often & 24 & 8.57 \\
\hline \multirow{5}{*}{$\begin{array}{l}\text { How long each time plays } \\
\text { social game on Facebook }\end{array}$} & Less than 30 minutes & 95 & 33.93 \\
\hline & 30 minutes- 1 hour & 115 & 41.07 \\
\hline & 1 hour -2 hours & 44 & 15.71 \\
\hline & 2 hours -3 hours & 19 & 6.79 \\
\hline & More than 3 hours & 7 & 2.50 \\
\hline \multirow{4}{*}{$\begin{array}{l}\text { How many social game plays } \\
\text { on Facebook }\end{array}$} & 1 game & 149 & 53.21 \\
\hline & 2 games & 85 & 30.36 \\
\hline & 3 games & 34 & 12.14 \\
\hline & More than 3 games & 12 & 4.29 \\
\hline
\end{tabular}


An Empirical Study on Determinants of Flow of Social Network Games on Facebook

$<$ Table 6> Exploratory factor analysis and internal consistency

\begin{tabular}{|c|c|c|c|c|c|c|c|c|c|}
\hline Variable & Item & \multicolumn{6}{|c|}{ Factor loading } & Eigenvalue & $\begin{array}{c}\text { Cronbach's } \\
\text { alpha }\end{array}$ \\
\hline \multirow{4}{*}{ Game Story (GS) } & GS1 & .370 & .100 & .207 & .267 & .267 & .701 & \multirow{4}{*}{4.323} & \multirow{4}{*}{0.897} \\
\hline & GS2 & .360 & -.029 & .187 & .296 & .296 & .664 & & \\
\hline & GS3 & .338 & .087 & .129 & .304 & .304 & .604 & & \\
\hline & GS4 & .093 & .296 & .115 & .100 & .100 & .731 & & \\
\hline \multirow{5}{*}{$\begin{array}{l}\text { Game Graphics } \\
\text { (GG) }\end{array}$} & GG1 & .752 & .156 & .273 & .274 & .147 & .193 & \multirow{5}{*}{3.871} & \multirow{5}{*}{0.929} \\
\hline & GG2 & .769 & .096 & .291 & .212 & .080 & .171 & & \\
\hline & GG3 & .683 & .159 & .324 & .261 & .185 & .160 & & \\
\hline & GG4 & .751 & .306 & .126 & .245 & .167 & .271 & & \\
\hline & GG5 & .748 & .168 & .160 & .135 & .194 & .376 & & \\
\hline \multirow{6}{*}{$\begin{array}{l}\text { Game } \\
\text { Socialization } \\
\text { (GSO) }\end{array}$} & GSO1 & .119 & .182 & .621 & .359 & .222 & .287 & \multirow{6}{*}{3.860} & \multirow{6}{*}{0.921} \\
\hline & GSO2 & .287 & .159 & 638 & .324 & .169 & .260 & & \\
\hline & GSO3 & .269 & .324 & .644 & .215 & .353 & .104 & & \\
\hline & GSO4 & .257 & .217 & .772 & .154 & .225 & .166 & & \\
\hline & GSO5 & .433 & .124 & .614 & .212 & .274 & .160 & & \\
\hline & GSO6 & .190 & .167 & .747 & .129 & .171 & .185 & & \\
\hline \multirow{4}{*}{$\begin{array}{l}\text { Game Control } \\
\text { (GC) }\end{array}$} & $\mathrm{GCl}$ & .223 & .226 & .208 & .827 & .201 & .122 & \multirow{4}{*}{3.717} & \multirow{4}{*}{0.942} \\
\hline & GC2 & .313 & .315 & .236 & .766 & .085 & .208 & & \\
\hline & GC3 & .351 & .265 & .238 & .720 & .149 & .088 & & \\
\hline & GC4 & .250 & .298 & .272 & .703 & .148 & .196 & & \\
\hline \multirow{5}{*}{$\begin{array}{l}\text { Perceived Ease } \\
\text { of Play (PE) }\end{array}$} & PE1 & .203 & .715 & .179 & .464 & .121 & .037 & \multirow{5}{*}{3.354} & \multirow{5}{*}{0.912} \\
\hline & PE2 & .215 & .750 & .194 & .273 & .023 & .280 & & \\
\hline & PE3 & .266 & .832 & .168 & .091 & .133 & .171 & & \\
\hline & PE4 & .049 & .713 & .098 & .098 & .417 & .128 & & \\
\hline & PE5 & .059 & .771 & .263 & .286 & .189 & .070 & & \\
\hline \multirow{4}{*}{ Flow (FL) } & FL1 & .356 & .137 & .225 & .253 & .651 & .214 & \multirow{4}{*}{3.242} & \multirow{4}{*}{0.918} \\
\hline & FL2 & .280 & .159 & .171 & .203 & .778 & .170 & & \\
\hline & FL3 & .067 & .190 & .256 & .046 & .821 & .164 & & \\
\hline & FL4 & .070 & .163 & .219 & .088 & .830 & .151 & & \\
\hline
\end{tabular}

\subsection{Confirmatory Factor Analysis and Validity}

First test of the main analysis is the validity and reliability checking. The reliability, convergent validity and discriminant validity of each constructs in the research model have been examined. Table 7 shows the result of confirmatory factor analysis for all constructs in the study. The next value is average variance extracted (AVE) which should be greater than 0.5 . It can be seen in Table 7 that all AVE values of seven constructs are satisfied the requirement. 
$<$ Table 7> Confirmatory factor analysis and validity

\begin{tabular}{|c|c|c|c|c|c|c|}
\hline \multicolumn{2}{|l|}{ Factor } & Estimate & SE & t-value & CR & AVE \\
\hline \multirow{4}{*}{ Game Story (GS) } & GS1 & 0.896 & 0.115 & 12.528 & \multirow{4}{*}{0.862} & \multirow{4}{*}{0.631} \\
\hline & GS2 & 0.830 & 0.107 & 11.952 & & \\
\hline & GS3 & 0.743 & 0.106 & 10.879 & & \\
\hline & GS4 & 0.693 & - & - & & \\
\hline \multirow{5}{*}{$\begin{array}{l}\text { Game Graphics } \\
\text { (GG) }\end{array}$} & GG1 & 0.862 & 0.046 & 19.263 & \multirow{5}{*}{0.934} & \multirow{5}{*}{0.719} \\
\hline & GG2 & 0.842 & 0.048 & 18.450 & & \\
\hline & GG3 & 0.807 & 0.047 & 17.112 & & \\
\hline & GG4 & 0.863 & 0.045 & 19.289 & & \\
\hline & GG5 & 0.866 & - & - & & \\
\hline \multirow{6}{*}{$\begin{array}{l}\text { Game } \\
\text { Socialization } \\
\text { (GSO) }\end{array}$} & GSO1 & 0.756 & 0.074 & 12.942 & \multirow{6}{*}{0.917} & \multirow{6}{*}{0.641} \\
\hline & GSO2 & 0.785 & 0.064 & 13.506 & & \\
\hline & GSO3 & 0.841 & 0.072 & 14.600 & & \\
\hline & GSO4 & 0.859 & 0.070 & 14.953 & & \\
\hline & GSO5 & 0.808 & 0.074 & 13.950 & & \\
\hline & GSO6 & 0.750 & - & - & & \\
\hline \multirow{4}{*}{$\begin{array}{l}\text { Game Control } \\
\text { (GC) }\end{array}$} & $\mathrm{GC1}$ & 0.884 & 0.049 & 20.296 & \multirow{4}{*}{0.945} & \multirow{4}{*}{0.793} \\
\hline & $\mathrm{GC} 2$ & 0.940 & 0.046 & 22.911 & & \\
\hline & $\mathrm{GC} 3$ & 0.875 & 0.050 & 19.921 & & \\
\hline & GC4 & 0.861 & - & - & & \\
\hline \multirow{5}{*}{$\begin{array}{l}\text { Perceived Ease of } \\
\text { Play (PE) }\end{array}$} & PE1 & 0.882 & - & - & \multirow{5}{*}{0.914} & \multirow{5}{*}{0.690} \\
\hline & PE2 & 0.860 & 0.052 & 19.633 & & \\
\hline & PE3 & 0.853 & 0.052 & 19.328 & & \\
\hline & PE4 & 0.696 & 0.069 & 13.728 & & \\
\hline & PE5 & 0.850 & 0.053 & 19.200 & & \\
\hline \multirow{4}{*}{ Flow (FL) } & FL1 & 0.836 & - & - & \multirow{4}{*}{0.861} & \multirow{4}{*}{0.674} \\
\hline & FL2 & 0.862 & 0.059 & 17.137 & & \\
\hline & FL3 & 0.800 & 0.071 & 15.426 & & \\
\hline & FL4 & 0.785 & 0.075 & 15.024 & & \\
\hline
\end{tabular}

* CR (Composite Reliability), AVE (Average Variance Extracted)

Table 8 represents the discriminant validity of the constructs. The goal of discriminant validity is to "evaluate how much a concept and its indicator variables differ from another concept and its indicator variables." (Shin and Shin, 2011) The square root of AVE value is used in discriminant validity. It should be "greater than the correlation shared between the construct and other constructs." (Fornell and Larcker, 1981). As summarized in Table 8, the square root of AVE of all constructs meets this criterion well. 
$<$ Table 8> Discriminant validity

\begin{tabular}{|l|r|r|r|r|r|r|}
\hline \multicolumn{1}{|c|}{ Variables } & Game Story & $\begin{array}{c}\text { Game } \\
\text { Graphics }\end{array}$ & $\begin{array}{c}\text { Game } \\
\text { Socialization }\end{array}$ & $\begin{array}{c}\text { Game } \\
\text { Control }\end{array}$ & $\begin{array}{c}\text { Perceived } \\
\text { Ease of Play }\end{array}$ & Flow \\
\hline Game Story & $\mathbf{0 . 7 9 4}$ & & & & & \\
\hline Game Graphics & 0.732 & $\mathbf{0 . 8 4 8}$ & & & & \\
\hline Game Socialization & 0.637 & 0.736 & $\mathbf{0 . 8 0 1}$ & & & \\
\hline Game Control & 0.606 & 0.717 & 0.720 & $\mathbf{0 . 8 9 0}$ & & \\
\hline Perceived Ease of Play & 0.476 & 0.527 & 0.632 & 0.692 & $\mathbf{0 . 8 3 1}$ & \\
\hline Flow & 0.607 & 0.574 & 0.699 & 0.526 & 0.538 & $\mathbf{0 . 8 2 1}$ \\
\hline
\end{tabular}

Diagonals represent the square root of average variance extracted, while the other matrix entries represent the shared variance (the squared correlations).

\subsection{Hypothesis Test}

The measurement model fit is performed by confirmatory factor analysis. Among various measures reflecting the model fit, seven common measures have been selected. As shown in Table 9, they are (1) Chi-square/degree of freedom (CMIN/DF); (2) the Goodness-of-Fit Index (GFI); (3) the Adjusted Goodness-of-Fit Index (AGFI); (4) Normed Fit Index (NFI); (5) Root Mean Square Error of Approximation
(RMSEA); (6) Root Mean square Residual (RMR); and (7) Comparative Fit Index (CFI). The recommended values from literature for these measures are also introduced in Table 9. CMIN/DF index, NFI index, RMSEA index and RMR index satisfy the acceptance threshold. The three left indices GFI, AGFI and CFI are approximately equivalent the suggested values. Therefore it could indicate that the measurement model has a good fit with the sampling or the structural model has a good model fit.

Table 10 exhibits the result of the hypotheses test. H1, H2, H3, H4, H5, H6 and H7 are well accepted with good significant values.

$<$ Table 9> Fit indices for the measurement model

\begin{tabular}{|l|c|l|}
\hline \multicolumn{1}{|c|}{ Fit Statistics } & Measurement model & \multicolumn{1}{c|}{ Recommended value } \\
\hline CMIN/DF & $\mathbf{2 . 0 7 5}$ & $<3$ (Hayduk, 1987) \\
\hline GFI & 0.895 & $>0.90$ (Bagozzi and Yi, 1988) \\
\hline AGFI & 0.788 & $>0.80$ (Fornell and Larcker, 1981) \\
\hline NFI & $\mathbf{0 . 9 1 8}$ & $>0.90$ (Fornell and Larcker, 1981) \\
\hline RMSEA & $\mathbf{0 . 0 4 8}$ & $<0.06$ (Joreskog and Sorbom, 1996) \\
\hline RMR & $\mathbf{0 . 0 6 0}$ & $<0.08$ (Bagozzi and Yi, 1988) \\
\hline CFI & 0.887 & $>0.90$ (Joreskog and Sorbom, 1996) \\
\hline
\end{tabular}


$<$ Table 10> Summary of hypotheses test

\begin{tabular}{|l|l|r|r|r|l|}
\hline Hypothesis & \multicolumn{1}{|c|}{ Path } & Estimate & t-value & p-value & \multicolumn{1}{|c|}{ Test } \\
\hline H1 & Game Story -> Flow & 0.286 & 3.394 & $* * *$ & Supported \\
\hline H2 & Game Graphics -> Flow & 0.516 & 5.548 & 0.004 & Supported \\
\hline H3 & Game Graphics -> Perceived Ease of Play & 0.677 & 4.969 & $* * *$ & Supported \\
\hline H4 & Game Socialization -> Flow & 0.527 & 5.040 & $* * *$ & Supported \\
\hline H5 & Game Socialization -> Perceived Ease of Play & 0.330 & 3.677 & $* * *$ & Supported \\
\hline H6 & Game Control -> Perceived Ease of Play & 0.519 & 6.327 & $* * *$ & Supported \\
\hline H7 & Perceived Ease of Play -> Flow & 0.342 & 2.011 & 0.044 & Supported \\
\hline
\end{tabular}

$* \mathrm{p}<0.05, * * \mathrm{p}<0.01, * * * \mathrm{p}<0.001$

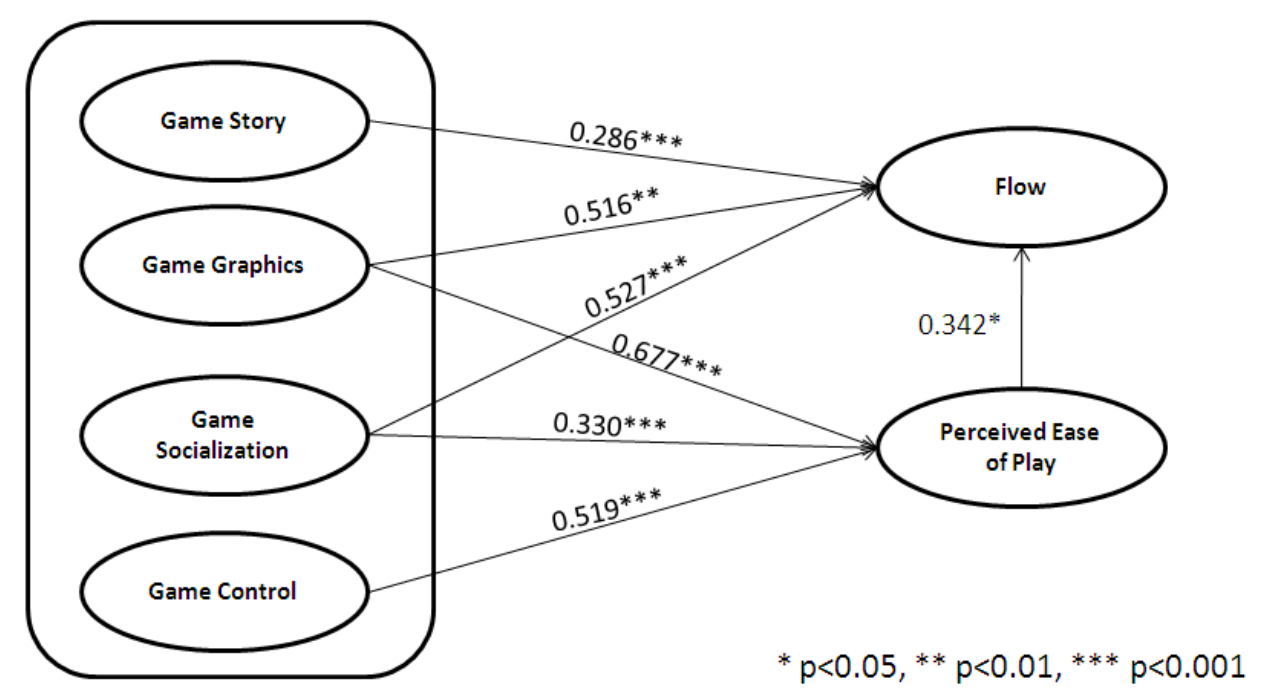

$<$ Figure 3> Results of structural equation model analysis

\section{Discussion and Implications}

\subsection{Discussion}

All seven hypotheses were supported. Game story, game graphics, and game socialization significantly and directly affect flow; while game control indirectly affects flow through perceived ease of play. Besides the main positive effect to flow, game graphics and game socialization have an additional effect on flow through perceived ease of play. Hence, it can be seen that game graphics and game socialization play a critical role in forming flow experience. In other words, game socialization can be considered the most important factor to flow experience of users. The socialization nature of social games has connected the users together; enabled them playing in the same community with the interaction with each other and the 
mutual support. The users feel that they are playing their own game due to the asynchronous playing mode but they are not lonely. Whenever they want to communicate and interact with other players through the social games, they can do it and vice versa. This kind of socialization nature quite provides the extremely interesting experience to the users. They feel more, enjoy more and relax more with the game. That could explain why many people prefer to play social games because the flow experience which social games bring to them. People play social games to entertain and feel being connected to the society, even it is a virtual social network. It is unique and distinct nature of games that are played on SNS, which is called SNG. Next to game socialization, game graphics and game story are also significant factor to flow. The nicer game graphics can enhance users' flow experience more and more. A social game might have a story, or just a simple puzzle game might be fine.

\subsection{Theoretical Implications}

From academic perspective, the study contributes to the understanding of SNG and its features, and what it distinguishes from other forms of game such as online game or offline game. Particularly, the social characteristics of SNG which leverages the distinctive point of social network sites makes social games become so new and interesting.
Second, it adds to a theoretical understanding of determinants which form the users' flow experience when playing SNG, whereas those factors are extracted from SNG. Those factors include game story, game graphics, game socialization and game control. Third, it shows the possibility that applying the combination of TAM and flow theory to explain a phenomenon in entertaining field. TAM is usually employed and extended for research on user acceptance of new technology, information system, and information service. There are also different previous researches applied a part of TAM to entertainment technology. The result of this study consolidates the possibility of employing TAM together to learn and explain the diverse topics in management information systems. Academic researchers can modify and improve the research model of this paper to perform a more enhanced study on SNG.

\subsection{Practical Implications}

From practical perspective, this paper highlights some notable points for SNG providers. First, it explains which characteristics of $\mathrm{SNG}$ forms the flow experience of $\mathrm{SNG}$ players. It also shows that the extent how much these factors affect the users' flow. Game socialization among other factors has a strong impact on user's flow experience. Hence, the SNG service providers can come up with how to improve their SNG in those aspects better, how 
to enhance the users' social and interaction better to maximize their enjoyment and playing experience.

Second, the study could draw a more holistic view of why and how the social network users enjoy and immerse themselves in SNG. The game story attracts the users. The game ability which enables the social interaction and cooperation inside the virtual game world makes the users more exciting about the game, and possibly motivate them enjoy the game more. It is because the game could be unreal, the social relationship and interaction are real. Besides, game graphics which is nice and comfortable for eyes and game control which is easy to learn, to use and to handle are quite important to the social game players. It ensures the continuous enjoyment and playfulness, so increasing and strengthening the flow experience of the players. The effects of game graphics and game control impact on flow through perceived ease of play. Therefore, perceived ease of play also has a critical role in creating flow experience. In case the users find out some difficulties of the social games and they think that they cannot overcome these difficulties, the users will leave the game. Because difficulties or some troubles in SNG could close-up and interrupt the enjoyment and flow experience of players, this situation can lead to a negative effect on SNG providers.

Third, SNG service providers can employ the findings of this study to build new business models or different strategies for their SNG. All current SNGs are free and also if the users want, they can pay money to achieve some more benefits and advantages. If the SNG service providers can understand, catch and capture the players' flow experience and playfulness, they can monetize through their SNG based on offering the right services. As introduced in Table 2, social game providers have some methods to monetize through their games. Several specific ways are suggested here. First, by leveraging game story, game designers can integrate the brand names of any company into the social games. Injecting a certain company brand name into the games is an implicit advertisement, so the social game providers can receive some money by doing that. But they have to utilize the game story cleverly, and make that integration interesting, logical and rational to the players. As shown in Figure 3, game story has significantly positive influence on flow. Building a fascinating story with the appearance of some brand names as a part of the game, the players won't feel being annoyed as they have to watch some advertisements on television or web sites. For an example, CityVille is a social game of Zynga on Facebook. The players can design and construct their own city which is similar to the city in reality. There are numerous of restaurants, different kinds of shops, supermarkets, hotels, government agencies, etc. Zynga is cleverly injecting Wal-Mart and Best Buy as the huge supermarket and retailer into CityVille. It may be a typical example of leveraging game 
story smartly. The other way is monetizing by improving the players' perceived ease of play to increase their flow. Social games always set the missions and challenges for the players to overcome. The players have to do something to obtain the goal and finish the mission. Some missions are easy, but some are difficult or require long time to complete. The game providers can offer the help to the players to pass those missions, by exchanging the special products, supports or aid with the real money. By providing some ways to help the players achieve the challenges easier and faster, it makes the improvements on perceived ease of use, so enhancing flow experience, therefore the players will be willing to buy or exchange those helps. Using the case of CityVille game, due to the coming Christmas the players may receive a mission like this. They have to build an amusement park serving only for the winter games such as snowball, skiing, and skating, and open it before Christmas 15 days. To construct the park, they have to collect enough the equipment and materials through some activities. It maybe takes long time to collect those parts, and the players are going to be overdue when they finish the part. So, they can exchange some money to buy the equipment they are lacking of, and then accomplishing the part. The key point is to keep and enhance the flow experience of players, so the game providers can impact on perceived ease of play. Another way is to increase game socialization, therefore having the direct influence to flow and indirect influence through perceived ease of play. The game companies should enhance the social game community on Facebook by making a formal fan page; sharing news, any updates, or changes on game features to the players; creating an environment for them to make new neighbors (friends playing together). A healthy community can foster the energetic and eager players. Moreover, they can maximally exploit the available social relationship of users on SNSs to sow and spread their SNG deeper and further in the social network community.

\section{Conclusion}

The research identified the antecedents of flow experience of users in playing SNG. It stressed on the characteristic of social games itself. Four specific characteristics of social games are game story, game graphics, game socialization and game control. Game story, game graphics, and game socialization were proposed as the direct determinants of flow. Perceived ease of play was also an antecedent of flow. Game graphics and game socialization also had an indirect effect on flow through perceived ease of play. Game control had indirectly influenced on the flow through perceived ease of play.

The academic and practical implications of the paper were represented. Nonetheless, the 
study has several common limitations. First, our samples might not be able to represent population. In addition, the number of measurement items is a little bit a lot (29 items). Totally 280 responses may not be enough. The ideal number of response should be about 320-350. As a part of empirical research, the research also has some limitations on sample bias. From Table 5, it is easy to find that the sample is biased on the respondents' gender and age. Female respondents are about 1.5 times more than male respondents. it is an unintended bias that happened during the survey process. Besides, nearly half of the respondent (43.57\%) is dominant by the 20 s people. This bias is explainable and fairly common for any empirical research which has been done in SNS environment. Young people tend to use SNS more than the other generations in both the quantity (the number of user) and the quality (the spending time) so it is understandable that's why the majority of respondent is from 20 years old to 29 years old. Next, the research model is likely the first and initial step in learning SNG. The research found the determinants of flow of SNG. There are probably still the further actions and behaviors after users' flow experience. For example, the users will continue play $\mathrm{SNG}$, introduce SNG to their friends, and pay money to the social game to invest their achievement in the game and enjoy the game more. The further study can leverage and explore to these directions to generalize the result of this study and contribute to further researches of SNG in particular and social network sites in general.

\section{References}

Bagozzi, R., and Yi, Y., "On the evaluation of structural equation models," Journal of the Academy of Marketing Science, Vol. 16, No. 1, 1988, pp. 74-94.

Bjork, S., "Principles and patterns of social games: Where's the difference compared to other games?," GCO Games Convention Online, 2010.

Bruner, G. C., and Kumar, A., "Explaining consumer acceptance of handheld Internet devices," Journal of Business Research, Vol. 58, No. 5, 2005, pp. 553-558.

Candy Crush Saga Wikipedia, http://en.wikipedia.org/wiki/Candy_Cr ush_Saga\#Popularity, 2013.

Causal Game Wikipedia, http://en.wikipedia.org/ wiki/Casual_gaming, 2013.

Chang, C., and Chin, Y., "Predicting the usage intention of social network games: an intrinsic-extrinsic motivation theory perspective," International Journal of Online Marketing, Vol. 1, No. 3, 2011, pp. 29-37.

Chen, H., Wigand, R. T., and Nilan, M. “Optimal experience of web activities," Computers in Human Behavior, Vol. 15, 
No. 5, 1999, pp. 585-608.

Choi, D., and Kim, J., "Why people continue to play online games: in search of critical design factors to increase customer loyalty to online contents," Cyber Psychology and Behavior, Vol. 7, No. 1, 2004, pp.11-24.

Csikszentmihalyi, M., Beyond Boredom and Anxiety. San Francisco, CA : Jossey-Bass, 1975.

Csikszentmihalyi, M., and Csikszentmihalyi, I. S., Optimal Experience: Psychological Studies of Flow in Consciousness, Cambridge UK : Cambridge University Press, 1988.

Csikszentmihalyi, M., Flow: The Psychology of Optimal Experience, New York, NY: Harper \& Row, 1990.

Davis, F., "Perceived usefulness, perceived ease of use, and user acceptance of information technology," MIS Quarterly, Vol. 13, No. 3, 1989, pp. 319-340.

Davis, F. D., Bagozzi, R. P., and Warshaw, P. R., "Extrinsic and intrinsic motivation to use computers in the workplace," Journal of Applied Social Psychology, Vol. 22, No. 14, 1992, pp. 1111-1132.

Eskelinen, M., "The gaming situation," Game Studies, Vol. 1, No. 1, 2001.

Finneran, C. M., and Zhang, P., "A Person-Artefact-Task (PAT) model of flow antecedents in computer-mediated environments," International Journal of
Human-Computer Studies, Vol. 59, No. 4, 2003, pp. 475-494.

Finneran, C. M., and Zhang, P., "Flow in computer-mediated environments: Promises and challenges," Communications of the Association for Information Systems, Vol. 15, No. 2, 2005, pp. 82-101.

Fornell, C., and Larcker, V. F., "Evaluating structural equation models with unobservable variables and measurement error," Journal of Marketing Research, Vol. 18, No. 1, 1981, pp. 39-50.

Fu, F. L., Su, R. C., and Yu, S. C., "EGameFlow: A scale to measure learners' enjoyment of e-learning games," Computers \& Education, Vol. 52, No. 1, 2009, pp. 101-112.

Gorby, P. E., How Zynga Makes Money, http://www.businessinsider.com/zyngarevenue-analysis-2011-9, 2011.

Hayduck, L., Structural Equation Modeling with LISREL, Baltimore : Johns Hopkings University Press, 1987.

Hoffman, D. L., and Novak, T. P., "Marketing in hypermedia computer-mediated environments: Conceptual foundations," Journal of Marketing, Vol. 60, No. 3, 1996, pp. 50-68.

Hsu, C. L., and Lu, H. P., "Why do people play on-line games? An extended TAM with social influences and flow experience," Information \& Management, Vol. 41, 
No. 7, 2004, pp. 853-868.

Hsu, C. L., and Lu, H. P., "Consumer behavior in online game communities: A motivational factor perspective," Computers in Human Behavior, Vol. 23, No. 3, 2007, pp. 1642-1659.

Ines, D. L., and Abdelkader, G., "Facebook games: between social and personal aspects," International Journal of Computer Information System and Industrial Management Applications, Vol. 3, No. 80, 2011, pp. 713-723.

Jeanne, H. B., Christine, M. F., Kathleen, A. C., Evan McBroom, Kimberly, M. B., and Jacquelyn, N. P., "The development of the Game Engagement Questionnaire: A measure of engagement in video game-playing," Journal of Experimental Social Psychology, Vol. 45, No. 4, 2009, pp. 624-634.

Joreskog, K. G., and Sorbom, D., LISREL 8: Users Reference Guide, Chicago : Scientific Software International, 1996.

Juul, J., "The Repeated Lost Art of Studying Games," Game Studies, Vol. 1, No. 1, 2001.

Kamis, A., Koufaris, M., and Stern, T., "Using an Attribute-Based DSS for User-Customized Products Online: An Experimental Investigation," MIS Quarterly, Vol. 32, No. 1, 2008, pp. 159-177.

Kirman, B., "Emergence and playfulness in social games," 14th International Academic Mindtrek Conference: Envisioning Future Media Environments, 2010, pp. 71-77.

Koo, D. M., "The moderating role of locus of control on the links between experiential motives and intention to play online games," Computer in Human Behavior, Vol. 25, No. 2, 2009, pp. 466-474.

Korzaan, M. L., "Going with the flow: Predicting online purchase intentions," Journal of Computer Information Systems, Vol. 43, No. 4, 2003, pp. 25-31.

Koufaris, M., Kambil, A., and LaBarbera, P. A., "Consumer behavior in Web-based commerce: An empirical study," International Journal of Electronic Commerce, Vol. 6, No. 2, 2002, pp. 115-138.

Koufaris, M., “Applying the technology acceptance model and flow theory to online consumer behavior," Information Systems Research, Vol. 13, No. 2, 2002, pp. 205-223.

Lin, C., Wu, S., and Tsai, R., "Integrating perceived playfulness into expectationconfirmation model for web portal context," Information \& Management, Vol. 42, No. 5, 2005, pp. 683-693.

Magic Media Futures, Social game audience growth is slowing in the U.S. - study, http://www.magid.com/node/221, 2012. Maiberg, E., The Top 25 Facebook games of May 
2013, http:/www.insidesocialgames.com/ 2013/05/01/the-top-25-facebook -gamesof-may-2013/, 2013.

Moon, J. W., and Kim, Y. G., "Extending the TAM for a WWW context," Information \& Management, Vol. 38, No. 4, 2001, pp. 217-230.

Murphy, C., "Why games work and the science of learning," Modsim World 2011 Conference, 2011.

Novak, T. P., Hoffman, D. L., and Yung, Y. F., "Measuring the customer experience in online environments: A structural modeling approach," Marketing Science, Vol. 19, No. 1, 2000, pp. 22-42.

Pearce, C., "Game noir-A conversation with Tim Schafer," Game Studies, Vol. 3, No. 1, 2003.

Phang, C. W., and Kankanhalli, A., "How do perceptions of virtual worlds lead to enhanced learing? An empirical investigation," Thirtieth International conference on Information Systems, 2009.

Radoff, J., Game On: Energize Your business with Social Media Games. Wiley, 2011, pp. 27-29, 39-40.

Rao, V., "Facebook Applications and playful mood: the construction of Facebook as a "third place", 12th international conference on Entertainment and media in the ubiquitous era, 2008.

Saarenpää, H., Korhonen, H., and Paavilainen, J.,
"Asynchronous gameplay in pervasive multiplayer mobile games," 27th international conference extended abstracts on Human factors in computing systems, 2009.

Schell, J., The Art of Game Design: a Book of Lenses, CRC Press, 2008.

Sharafi, P., Hedman, L., and Montgomery, H., "Using information technology: Engagement modes, flow experience, and personality orientations," Computers in Human Behavior, Vol. 22, No. 5, 2006, pp. 899-916.

Shin, D. H. and Shin, Y. H., "Why do people play social network games?," Computers in Human Behavior, Vol. 27, No. 2, 2011, pp. 852-861.

Skadberg, Y. X., and Kimmel, J. R., "Visitors' flow experience while browsing a Web site: Its measurement, contributing factors and consequences," Computers in Human Behavior, Vol. 20, No. 3, 2004, pp. 403-422.

Smith, J., "State of social gaming industry," GDC 2010, 2010.

Social Network Game Wikipedia, http://en.wikipedia.org/wiki/Social_net work_game, 2013.

Sung, J., Bjornrud, T., Lee, Y. H., and Wohn, D. Y., "Social network games: exploring audience traits," 28th Annual CHI Conference on Human Factors in Computing Systems (CHI '10), 2010, pp. 
3649-3654.

Sweetser, P. and Wyeth, P., "Game flow: a model for evaluating player enjoyment in games," ACM Computer in Entertainment, Vol. 3, No. 3, 2005, pp. 1-25.

Taylor, L., Why social media gaming is big business for your business?, http://www.socialmediaexaminer.com/ why-social-media-gaming-is-big-busin ess-for-your-business/, 2010.

Trevino, L. K., and Webster, J., "Flow in Computer-mediated Communication," Communication Research, Vol. 19, No. 5, 1992, pp. 539-573.

Van der Heijden, H., "User acceptance of hedonic information systems," MIS Quarterly, Vol. 28, No. 4, 2004, pp. 695-704.

Venkatesh, V., "Determinants of perceived ease of use: Integrating control, intrinsic motivation, and emotion into the technology acceptance model," Information systems research, Vol. 11, No. 4, 2000, pp. 342-365.

Wei, X., Yang, J., and Adamic, J. A., "Diffusion dynamics of games on online social networks," 3rd Conference on Online Social Networks (WOSN'10), 2010.

Williams, D., "Why game studies now? Gamers don't bowl alone," Games and Culture, Vol. 1, No. 1, 2006, pp. 13-16.

Wohn, D. Y., Lampe, C. and Wash, R., Ellison, N., and Vitak. J., "The "S" in social network games: Initiating, Maintaining, and
Enhancing Relationships," 44th Hawaii International Conference on System Sciences, 2011.

Woollaston, V., Candy Crush Saga soars above Angry Birds to become WORLD'S most popular game,

http://www.dailymail.co.uk/sciencetech /article-2324228/Candy-Crush-Saga-ov ertakes-Angry-Birds-WORLDS-popula r-game.html, 2013.

Wu, J., Li, P., and Rao, S., "Why they enjoy virtual game worlds? An empirical investigation," Journal of electronic commerce research, Vol. 9, No. 3, 2008, pp. 219-230.

Wu, Y., Wang, Z., Chang, K., and Xu, Y., "Why people stick to play social network site based entertainment applications: Design Factors and Flow Theory Perspective," AMCIS Conference in Taiwan, 2010. 


\section{당응웬하인 (Hanh-Nguyen Tang)}

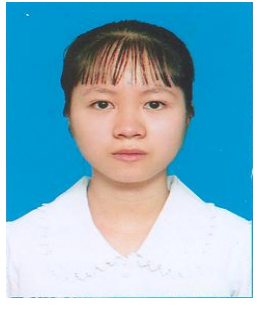

Ms. Tang Nguyen Hanh is currently a $\mathrm{PhD}$ student of Department of Information Management at Dongguk University-Gyeongju Campus in Korea. She has finished her Master course of the same department and now tried to do a further step. Ms. Tang was graduated from Information Technology Department in Vietnam as an engineer, then she has continued studying under Management Information Systems (MIS) field as now. Ms. Tang's research interests include enterprise systems, open source software, cloud computing, social network sites, business intelligence, multi-criteria decision making, etc.

\section{주재훈 (Jaehun Joo)}

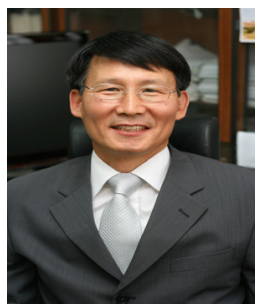

현재 동국대학교(경주캠퍼 스) 경영·관광대학 경영학부 교수로 재직 중이다. 부산대학 교에서 경영학박사 학위를 취 득하였다. 현재 한국경영정보 학회 부회장을 맡고 있고, 한국 정보시스템학회 회장과 편집

위원장을 역임하였다. 주요 관심분야는 전자상거래, 비즈니스 생태계, e-비즈니스 전략, 시맨틱 웹, 지식경 영, 집단지성과 소셜웹 등이다. 경영학연구, APJIS, 한 국경영과학회지, 정보시스템연구, Journal of Human-Computer Studies, Service Business, Journal of Sustainable Tourism, DSS, Information Systems Management, International Journal of Industrial Engineering, Expert Systems with Applications, Journal of Computer Information Systems 등에 다수의 논문을 게재하였다. 
<국문요약>

\title{
페이스북의 소셜게임에서 몰입에 영향을 주는 요인에 대한 실증연구
}

\author{
당응웬하인 · 주재훈
}

소셜 네트워크 서비스의 확산과 더불어 소셜 네트워크 게임(이하에서는 소셜게임이라 함)이 부 각되고 있다. 한편, 소셜게임이 인기를 끌면서 소셜 네트워크 서비스가 더욱 확산되는 계기가 되 기도 한다. 사용자들을 소셜게임에 몰입하도록 유인하는 요인이 무엇인가를 파악하면 소셜 네트 워크 서비스가 더욱 발전할 수 있는 방안을 찾을 수 있다. 따라서 본 연구는 사용자들을 소셜게임 에 몰입하도록 유인하는 요인이 무엇인가를 분석하는데 있다. 본 연구에서는 대표적인 소셜 네트 워크 사이트라 할 수 있는 페이스북의 소셜게임 사용자들을 대상으로 설문조사를 실시하였다. 280 명의 사용자들을 대상으로 한 설문을 통해, 소셜게임에의 몰입, 게임스토리, 게임그래픽, 게임 사회화, 게임 통제력, 게임 사용용이성의 관계를 구조방정식모형으로 분석하였다. 특히, 게임 사회 화와 게임그래픽은 몰입에 직접적으로 영향을 주기도 하며 게임 사용용이성을 통해 간접적으로도 영향을 주었다. 한편, 게임스토리는 몰입에 직접적으로만 영향을 주고, 게임 통제력을 게임 사용 용이성을 통해 간접적으로 영향을 준다. 본 연구는 몰입이론과 기술수용이론을 토대로 하고 있지 만, 소셜게임에서의 몰입에 대한 최초의 연구이기 때문에 후속 연구에 지침이 될 수 있다. 또한 소셜게임을 개발하는 사업자들이 무엇에 역점을 두고 게임을 개발하고 서비스해야 할 것인가에 대한 지침이 될 수 있다.

Keywords: Social games, flow, Facebook, social network sites, social network games, flow experience, SNS.

* 이 논문은 2013년 7월 30일 접수하여 2차 수정을 거쳐 2013년 12월 17일 게재 확정되었습니다. 